\title{
Oral Kontraseptif Kullanımının Sağlık ve Serum Mikro Besin Ögesi Seviyeleri Üzerine Etkisi
}

\author{
Effect of Oral Contraceptive Use on Health and Serum Micronutrient Levels
}

\author{
Merve Esra Çıtar Dazıroğlu¹, Yasemin Akdevelioğlu²
}

Geliş tarihi/Received: 30.06.2020 • Kabul tarihi/Accepted: 29.06.2021

\section{ÖZET}

Dünya genelinde, doğurganlık çağındaki kadınlar tarafından yaygın bir şekilde kullanılan oral kontraseptifler (OK), doğum kontrolünün yanı sıra birtakım hastalıkların tedavisi amacı ile de tercih edilebilmektedir. Piyasada ilk tanıtıldığı 1960 yılından bu yana OK'lerin içeriğinde, başta östrojen dozunun azaltılması olmak üzere pek çok değişiklik yapılmıs ve bu şekilde olası yan etkilerin azaltılması amaçlanmıştır. Bununla birlikte, günümüz OK’lerinin kullanımında da çeşitli sağlık ve beslenme sorunları devam etmektedir. Sağlık sorunlarının başında tromboembolizm ve bazı kanser türlerinin artışı gelmektedir. Beslenme konusunda, OK kullanan kadınlarda besin ögesi gereksinimlerinde değişiklik olup olmadığı kesin olarak bilinmediği için beslenmelerinde yapılacak değişiklikler konusu da net değildir. Bununla birlikte, OK kullanımının, başta $B_{6}$ vitamini, $B_{12}$ vitamini, $C$ vitamini, folik asit ve çinko olmak üzere birçok mikro besin ögesi yetersizlikleri ile ilişkili olduğu belirtilmektedir. Bu nedenle, OK kullanan kadınlarda da optimum sağlık için temel rol oynayan optimum beslenmenin sağlanması, bu bireylerde erken dönemde alınacak önlemler ile mümkündür. OK kullanımına bağlı olası mikro besin ögesi yetersizliklerini önlemek için, beslenmenin değerlendirilmesi sonrasında, yeterli ve dengeli beslenmenin sağlanması veya gerekli olduğu takdirde hekim tavsiyesi ile besin takviyesi kullanımı, birinci basamakta çözüm önerisi olarak düşünülmelidir.

Anahtar kelimeler: Oral kontraseptif, sağllk, beslenme, mikro besin ögeleri

\begin{abstract}
Oral contraceptives (OC), which are widely used by women of reproductive age worldwide, can be preferred for the purpose of treating certain diseases as well as birth control. Since the first time it was introduced in the market, many changes have been made in the content of OCs, especially in reducing the dosage of estrogen, and in this way, it is aimed to reduce the possible side effects; however, various health and nutrition problems continue in the use of OCs today. The most important of health problems are the increase in thromboembolism, some types of cancer. When nutritional problems are examined, it is not clear whether there is a change in nutritional requirements in women using OC, so it is not clear whether there will be changes in their diet. However, it is stated that the use of $\mathrm{OC}$ is associated with deficiencies of many micronutrients, especially vitamin $\mathrm{B}_{6}$, vitamin $\mathrm{B}_{12}$, vitamin $\mathrm{C}$, folic acid and zinc. Therefore, providing optimum nutrition, which plays a fundamental role for optimum health, is possible with early precautions in these individuals. In order to prevent possible micronutrient deficiencies, providing adequate and balanced nutrition after evaluation of nutrition or the use of food supplements with the recommendation of a physician should be considered as a first-line solution recommendation.
\end{abstract}

Keywords: Oral contraceptive, health, nutrition, micronutrients

1. İletişim/Correspondence: Gazi Üniversitesi, Sağllk Bilimleri Fakültesi, Beslenme ve Diyetetik Bölümü, Ankara, Türkiye

E-posta: esracitar@gmail.com • 『 https://orcid.org/0000-0002-7060-6265

2. Gazi Üniversitesi, Sağllk Bilimleri Fakültesi, Beslenme ve Diyetetik Bölümü, Ankara, Türkiye • ๑ https://orcid.org/0000-0002-2213-4419 


\section{GíRIŞ}

Oral kontraseptifler (OK) genel olarak doğum kontrolü amacı ile kullanılmakla birlikte menstrüel ağrı, düzensiz menstrüasyon ve uterus miyomları başta olmak üzere çeşitli hastalıklarda tedavi amacı ile de tercih edilebilmektedir (1). OK'lerin yan etkileri, içerdikleri östrojen dozu ile ilişkilidir (2). Bu nedenle, ilk OK’ler de 1960 yllında piyasaya sürülmelerinden bu yana, etki gücünü yitirmeden, yan etkilerin en aza indirilmesi ve iyileştirilmeleri doğrultusunda, başta östrojen dozunu azaltmak üzere pek çok gelişme yaşanmıştır. Geçmişten bugüne yaşanan ilerlemelere rağmen, OK'lerin kullanımından kaynaklanan sorunlar hala devam etmektedir (3).

OK’ler tromboembolizm, miyokart enfarktüsü ve inme gibi ciddi sağlık sorunlarına yol açmanın $(4,5)$ yanı sıra, $\mathrm{B}_{6}$ vitamini, $\mathrm{B}_{12}$ vitamini (6), C vitamini (7), folik asit (8) ve çinko (9) gibi birçok besin ögesinin yetersizliği riskini de taşımaktadır (5). OK kullanan kadınlarda, kullanmayanlara göre daha düşük kan mikro besin ögesi seviyelerinin olması, söz konusu vitamin ve mineraller için daha yüksek miktarda gereksinim ile ilişkilendirilmektedir (10). Bu besin ögelerinin doku seviyelerinde veya biyoyararlanımlarındaki değişiklikler ise çeşitli sağlık risklerini beraberinde getirmektedir (9). Dolayısı ile OK kullanımının olası etkilerinin bilinmesinin, bu bireylerde erken dönemde önlem alma açısından faydalı olacağı açıktır. $\mathrm{Bu}$ derlemede OK'lerin sağlık üzerindeki potansiyel etkilerinin yanı sıra, OK kullanımı sonucu mikro besin ögelerinde görülen değişim, nedenleri ile birlikte sunulmaktadır.

\section{Oral Kontraseptifler}

Talimatlara uygun olarak kullandığında koruyuculuklarının \%99'dan daha fazla olduğu düşünülen OK'ler (11), günümüzde dünya çapında doğurganlık çağındaki kadınlar tarafından yaygın bir şekilde kullanılmakta ve en etkili farmakolojik ajanlardan biri olarak kabul edilmektedir (12). Hastalıkları Kontrol ve Önleme Merkezi (Centers for Disease Control and Prevention-CDC) tarafindan hazırlanan 2015-2017 raporuna göre Amerika'da 15-49 yaş arasındaki kadınların \%12.6’sı OK kullanmaktadır (13). Ülkemizde 2018 Türkiye Nüfus ve Sağlık Araştırması (TNSA) verilerine göre ise, 1549 yaş arasındaki kadınların \%4.8'i OK kullandığını belirtmekte ve geçmişten günümüze olan değişim incelendiğinde (1988 yllında OK kullanımı \%6.2) OK kullanımında bir azalma olduğu dikkat çekmektedir (14).

OK'ler östrojen ve progestini birlikte içeren kombine oral kontraseptifler ve minipill de denilen yalnızca progestin içeren haplar olmak üzere iki kategoride incelenmekledir. En sık kullanılan ise kombine oral kontraseptiflerdir (11). Kombine oral kontraseptifler içerisinde bulunan progesteronun temel etki mekanizması foliküler gelişimi engelleyerek ovülasyonu önlemektir. Östrojen ise menstrüel kanamayı kontrol etmektedir (1).

Amerika Birleşik Devletleri Gıda ve İlaç Dairesi (Food and Drug Administration-FDA) tarafindan 1960’ta onaylanmış olan ve Enovid adı verilen ilk kombine oral kontraseptif, mestranol ve noretynodrel içermektedir. Bir östrojen olan mestranolün bu ilk haptaki dozu 150 $\mu \mathrm{g}$, bir progestin olan noretynodrelin ise başlangıç dozu hap başına 9.85 mg’dir. $50 \mu \mathrm{g}$ mestranolün, $35 \mu \mathrm{g}$ etinil estradiole (EE) farmakokinetik olarak biyoeşdeğer olmasından dolayı hapta bulunan başlangıç östrojen dozu çok yüksek düzeydedir (12). Bununla birlikte, ilk tanıtılan diğer OK'ler de 500 g'a kadar mestranol veya $150 \mu$ g’a kadar EE içermektedir (2). İlk klinik çalışmalarda, Enovid'in kontraseptif etkinliği mükemmel olsa da bu ilaç birçok yan etkiye de neden olmuş ve 1961'de bu ilacı kullanan bir kadının trombozdan öldüğü bildirilmiştir (12). Bunun ardından kombine oral kontraseptiflerin içerdiği östrojen dozu yıllar içerisinde giderek azaltılmış (3) ve günümüzdeki $20 \mu$ g’den daha az düzeyde östrojen bulunduran OK'ler piyasaya sürülmüştür (15). Aynı zamanda östrojen ve progestin türleri de zamanla değişmiş ve önceden OK'ler mestranol içerse de zamanla onun yerini EE’ler almıştır (2). 


\section{Oral Kontraseptiflerin Sağllk ile İlişkisi}

OK'ler dismenore, menoraji, hiperandrojenizm, polikistik over sendromu, akne, endometriozis, endometriozise bağlı pelvik ağrı, premenstrüel sendrom, bazı kanser türleri (endometrium, over kanseri gibi), menstrüel migren gibi çoğunlukla jinekolojik sorunlarda tedavi amaçlı kullanılabilmektedir $(15,16)$. OK'ler tedavi amaçlı kullanılmalarının yanı sıra over ve uterus kanseri gibi bazı kanser türlerinin görülme riskini azaltarak sağlığa olumlu yönde katkıda bulunmaktadırlar. OK'lerin aynı zamanda, romatoid artrit riskinde azalma ve dış gebeliğin önlenmesi üzerinde de faydalı etkiye sahip oldukları belirtilmektedir (17).

Bununla birlikte, yeni nesil OK kullanımına bağlı olarak bazı sağlık risklerinin olduğu da bilinmektedir (18). OK'ler depresyon, migren baş ağrısı gibi çeşitli yan etkilerinin yanı sıra meme ve serviks kanseri (18), felç (17), kardiyovasküler hastalıklar (19), inflamatuvar bağırsak hastalığı (20), iyi huylu veya kötü huylu karaciğer tümörü ve tanı konulmamış anormal vajinal kanama (17) gibi ciddi birtakım sağllk sorunlarının görülmesinde artışa yol açabilmektedir. Bütün bunların yanında, OK kullanımının obezite riskini arttırdığı da bilinmektedir. Obezite ile OK arasındaki ilişkinin altında yatan mekanizmada ise leptin konsantrasyonlarındaki değişiklikler veya inflamatuvar yanıttaki artışlar olduğu düşünülmektedir (10).

Bütün bunlardan dolayl, OK'lerin kullanımı konusunda, klinisyenler tarafindan fayda ve zararlar ayrıntılı olarak düşünülmeli ve kullanımına titizlikle karar verilmelidir (11).

\section{Oral Kontraseptiflerin Mikro Besin Ögeleri ile İlişkisi}

OK'lerin besin ögesi gereksinimlerini değiştirip değiştirmediğine dair kesin bir kanıt mevcut olmadığ 1 için OK kullanıcılarının diyetlerinde yapılması gereken değişikliklere ilişkin de bir netlik söz konusu değildir. Bununla birlikte, OK kullanan kadınlarda, kullanmayanlara kıyasla bazı mikro besin ögelerinin biyokimyasal seviyelerinde değişimler görüldüğü için OK'ler uzun zamandır daha düşük biyokimyasal mikro besin ögesi seviyeleri ile ilişkilendirilmektedir (21). Bu nedenle, OK kullanıcılarında C vitamini ve folik asit gibi yetersizlik riski bulunan birtakım mikro besin ögelerinin alımını artırmaya yönelik çabaların dikkate alınması gerekliliği vurgulanmaktadır (10). Ancak bu genellemenin bütün OK kullanıcılarında geçerli olup olmayacağının belirlenebilmesi için yapılacak olan daha kapsamlı çalışmalara ihtiyaç vardır. Çünkü bu durum, OK kullanan kadınların diyetlerinin yeterli ve dengeli olup olmadığı ile yakından ilişkilidir. Diyetleri yeterli ve dengeli olmayan kadınların OK kullanımı ile birlikte beslenme sorunlarının daha da artabileceği açıtır. Özellikle de OK kullanımını bıraktıktan hemen sonra gebe kalan kadınlar için beslenmedeki bu problemler, daha ciddi sonuçlar doğuracaktır. Bundan dolayı, OK kullanımı ile birlikte biyokimyasal mikro besin ögesi düzeylerinde görülmesi olası değiş̧ikliklerin bilinmesi ve bu doğrultuda kadınların beslenmelerine erken müdahalede bulunulması büyük önem taşımaktadır (8). OK kullanımı ile bazı mikro besin ögelerinde, biyokimyasal seviyede görülmesi beklenen değişiklikler, Şekil 1'de gösterilmektedir.

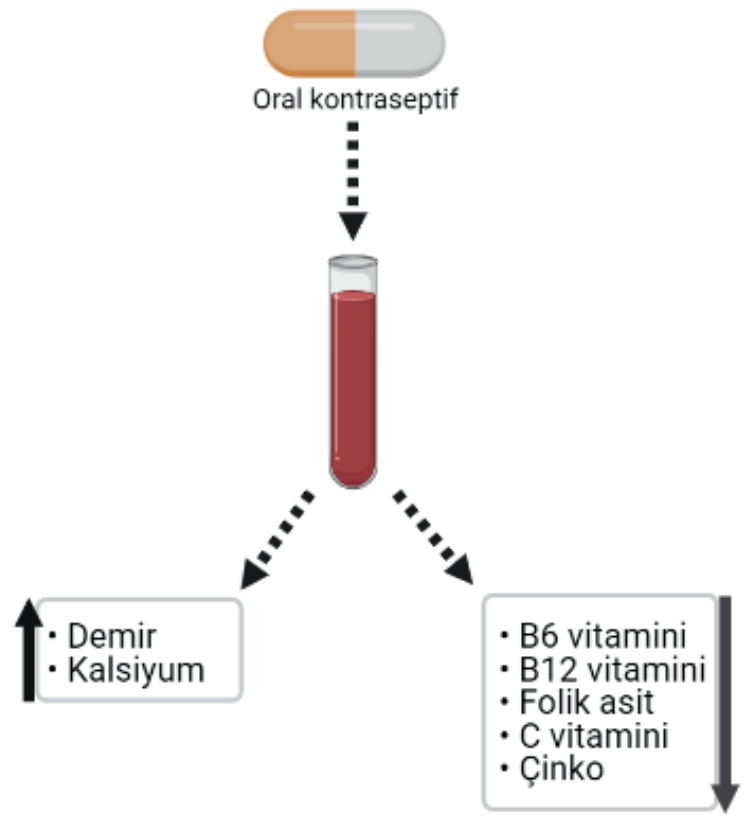

Şekil 1. OK kullanımı ile bazı mikro besin ögelerinin kan seviyelerinde görülen değişimler 
B $_{6}$ vitamini: Son zamanlarda Morris ve ark. (22) tarafından 2008 yılında yapılmış büyük ölçekli popülasyon tabanlı bir çalışmada, plazma piridoksal fosfat (PLP) konsantrasyonunun, OK kullanıcisı olan bireylerin büyük çoğunluğunda düşük olduğu görülmüştür. $\quad B_{6}$ vitamini alımının yeterliliğini de değerlendiren bu araştırmadan elde edilen bulgular, OK kullanıcılarında yeterli $\mathrm{B}_{6}$ vitamini seviyelerini korumak için mevcut gereksinim (1.3 mg/gün) önerilerinden daha yüksek alımların (3 mg/gün) gerekli olabileceğini düşündürmektedir (22). OK kullanan ve kullanmayan kadınların serum $\mathrm{B}_{6}$ vitamini düzeylerinin kıyaslanması amacı ile yapılmış başka bir çalışmada da OK kullananların kullanmayanlara kıyasla daha düşük serum $\mathrm{B}_{6}$ düzeyi gösterilmiştir. Aynı çalışmada, OK kullanıcılarındaki düşük $B_{6}$ vitamini plazma seviyeleri; artan triptofan oksijenaz aktivitesi ve östrojen metabolitlerinin $\mathrm{B}_{6}$ koenzimlerinin $\mathrm{B}_{6}$ 'ya bağımlı enzimlere bağlanmasına müdahale etmesi sonucu artan vitamin gereksinimine atfedilebilmektedir (6).

$\mathbf{B}_{12}$ vitamini: Çeşitli çalışmalar $(6,23,24)$ ve sistematik bir derleme (25), OK kullanımının serum $B_{12}$ düzeyinde bir düşüş ile ilişkili olduğunu ortaya koymuştur. OK kullananların idrar $B_{12}$ atımları normal olmasına rağmen serum seviyelerinde görülen bu düşüklük, toplam $B_{12}$ vitamini bağlama kapasitesi ve transkobalamin I düzeylerinin düşük olması ile açıklanabilmektedir (26). Buna ek olarak, $\mathrm{B}_{12}$ seviyesinin serum konsantrasyonlarındaki azalma gerçek bir kobalamin eksikliğini de göstermeyebilir. Bu durum, metilmalonikasit (MMA) konsantrasyonları gibi fonksiyonel kobalamin göstergelerinde değişiklik olmaması ile desteklenmektedir (25). Çünkü idrar MMA konsantrasyonları (27) ile plazma MMA (23) konsantrasyonlarının OK kullananların kullanmayan kontrollere kıyasla aralarında hiçbir fark olmadığı saptanmıştır.

Folik asit: Yakın zamanda yapılan bir meta analizden elde edilen veriler, OK kullanımının kan folat konsantrasyonunun düşmesi ile ilişkili olduğunu göstermiş ve kadınların OK kullanımı sirasinda, folat takviyesine devam etmesinin zorunlu olduğu vurgulanmıştır (8). Erken dönemlerde de OK kullanımının serum (28) ve kırmızı kan hücresi folat düzeylerini olumsuz etkileyebileceği hipotezi ortaya konmuştur (29). OK kullanımı ile folik asit yetersizliği arasındaki bağlantı için çeşitli mekanizmalar önerilmiştir. İlk olarak, poliglutamil folat formunun emilimi, OK kullanan bireylerde, kullanmayanlara kıyasla yaklaşı \%50 daha düşüktür; çünkü OK, poliglütamil folatın bağırsaktan emilimini bozabilmektedir. İkincisi ise OK, folatın böbreklerden geri emiliminde rol oynayan karaciğer enzimlerinde veya renal folat bağlama proteinlerinde birtakım değişikliklere neden olarak, kandaki folatın klirensini artırabilmektedir. Son olarak da, OK kullanımı folat gerektiren mikrozomal enzimlerin artan aktivitesi ile birlikte folat metabolizmasının bozulmasına yol açabilmektedir (25).

C vitamini: OK kullanan kadınların serum askorbik asit konsantrasyonlarının OK kullanmayanlara kıyasla önemli düzeyde daha düşük olduğu gösterilmiştir (7). Zal ve ark. (2012) tarafından yapılan bir çalışmada, OK kullanımının artan oksidatif stres ile ilişkili olması nedeni ile $\mathrm{E}$ ve $\mathrm{C}$ vitamini takviyelerinin bu olumsuz etkiyi azaltıp azaltamayacağı incelenmiştir. Çalışma sonucunda düşük doz OK kullanan kadınlarda kontrol grubuna kıyasla azalmış glutatyon peroksidaz (GPx) ve glutatyon redüktaz (GR) aktivitelerinin yanı sira plazma malondialdehit seviyelerinde önemli artışlar bildirilirken, düşük doz OK kullanan ve $C$ ve $E$ vitaminleri ile takviye edilen gruptaki kadınlarda ise GPx ve GR aktivitesini önemli ölçüde arttığı ve plazma malondialdehit seviyelerinin azaldığı gözlenmiştir (30). OK kullanımı ile C vitamini arasındaki bu bağlantı için, östrojenin $\mathrm{C}$ vitamini metabolizmasını artırabileceği ve OK'lerin kullanımının bu vitaminin lökositlerde ve trombositlerde doku alım örüntülerinde ve dağllımdaki değişikliklerle ilişkili olarak bu vitaminin seviyelerinin azalmasina neden olabileceği düşünülmektedir (5). Buradan hareketle bu vitaminlerle takviyenin kontraseptif ilaçların neden olduğu potansiyel birtakım risklere karşı koruyucu olabileceği düşünülmektedir (30). 
Kalsiyum: OK kullanımı hem premenopozal hem de postmenopozal kadınlarda artmış kortikal ve trabeküler kemik kütlesi ve daha yüksek kemik mineral yoğunluğu ile ilişkilendirilmiştir (31). Uzunlamasına yapılmış olan bir çalışmada da OK'lerin genç yetişkinlik dönemindeki kadınlar tarafından perimenopoza kadar kullanılmasının kemik-mineral yoğunluğu üzerinde yararlı bir etkisinin olabileceği bildirilmiştir (32). Premenopoz öncesi oligomenoresi olan kadınlarda OK kullanımının iki yıllık süreç sonrasinda, osteokalsin plazma düzeyleri ile idrarla hidroksiprolin atılımının önemli ölçüde azaldığı ve sonuçta femoral kemik yoğunluğunda önemli bir artışa neden olduğu görülmüştür (33). OK kullanımının, üriner kalsiyum kaybını azalttığı ve genç kadınlarda kemik turnover'ını yavaşlattığı saptanmıştır (34).

Demir: Daha kısa kanama süresi (35) ve daha az kan kaybı (36) ile ilişkili olan OK kullanımının, bu özelliklerinden dolayı demir seviyelerini olumlu yönde etkileyebileceği ifade edilmektedir. Bununla birlikte, östrojenin transferrin ve ferritin gibi akut faz proteinlerinin hepatik sentezini indüklediği bilinmektedir (10). Bunlarm da OK kullanan kadınlarda kullanmayanlara klyasla serum demir düzeylerinin daha yüksek olması ile ilişkili olabilecek mekanizmalar olduğu düşünülmektedir $(9,21)$.

Çinko: OKkullanımı, metabolizmada çinkonun plazma konsantrasyonlarının azaltılması ve toplam vücut depolarının etkilenmesine neden olabilmektedir (37). Aynı zamanda, OK'lerin hemodilüsyon yoluyla serum çinko konsantrasyonunu baskıladığı bilinmektedir. Bunlardan dolayı da OK kullanan kadınlarda serum $(9,38,39)$ ve idrar (21) çinko düzeylerinin azaldığı çeşitli çalışmalarda gösterilmiştir. OK kullanımının doku çinko alımını artırması, doku çinko salınımını azaltması ve doku çinko turnover'ında azalmaya neden olması sonucunda, kadınların çinko seviyelerinde azalmaya neden olabileceği belirtilmiştir $(21,38)$. Bununla birlikte, östrojenlerin karaciğerdeki proteinlerin biyosentezini uyardığı bilinmektedir (21). Protein sentezi ile bu sürece dahil olan birçok enzim için de çinko gerektiğinden (40), OK kullanıcılarındaki düşük serum ve idrar çinko seviyelerinin nedeninin, OK’nin anabolik etkisi için gereken karaciğer çinko alımının artması ile ilişkili olabileceği ifade edilmektedir (21).

\section{SONUÇ VE ÖNERİLER}

OK'lerin kullanımında tromboembolizm ve bazı kanser türleri başta olmak üzere ciddi hastalık riskleri ile de ilişkili olan bazı sorunların olabileceği uzun zamandır bilinmektedir. $\mathrm{Bu}$ hastalıkların etiyolojisinde beslenmenin yeri olduğu kadar, OK’lerin aynı zamanda çeşitli besin ögesi yetersizliklerinin riskini arttırdıkları da açıkça görülmektedir. OK kullanımının biryan etkisi olarak, bazı besin ögelerinin düşük kan seviyeleri, OK kullanan kadınların daha yüksek miktarda vitamin ve minerallere ihtiyaç duyabileceklerini düşündürmektedir. Dolayısı ile OK'lerin neden olduğu besin ögesi yetersizliklerinin olumsuz sonuçlarını ortadan kaldırabilmek adına bireylerin rutin kontrollerini aksatmamaları önemlidir. Bir yetersizlik olması durumunda, diyetisyen kontrolünde $\mathrm{B}_{6}$ vitamini için et, kurubaklagil, tam tahıl ürünleri; $\mathrm{B}_{12}$ vitamini için et ve süt ürünleri; folik asit için kurubaklagil, yağlı tohumlar, koyu yeşil yapraklı sebzeler; çinko için et, yağlı tohum ve $\mathrm{C}$ vitamini için de meyve-sebze tüketiminde dengeli artışlar sağlanmalıdır. Diyetle mikro besin ögelerinin alımında artışın yapılmasının yeterli olmadığı durumlarda ise hekim tavsiyesi doğrultusunda besin takviyesinden yaralanmaları gerekmektedir. Sonuç olarak, bu ilaçların olası sağlık ve beslenme sorunlarının önüne geçebilmek adına, risklerin bilinmesi ve bu doğrultuda erken tedbir alınması oldukça büyük önem taşımaktadır.

Çıkar çatışması - Conflict of interest: Yazarlar çıkar çatışması olmadığını beyan ederler. - The authors declare that they have no conflict of interest.

Yazarlık katkısı - Author contributions: Çalışmanın tasarımı: MEÇD, YA; İlgili literatürün taranmast: MEÇD; Makale taslağının oluşturulması: MEÇD; İçerik için eleştirel gözden geçirme: YA; Yayınlanacak versiyonun son onayl: MEÇD, YA - Study design: MEÇD, YA; Literature review: $M E C ̧ D$; Draft preparation: $M E C ̧ D$; Critical review for content: YA; Final approval of the version to be published: MEÇD, YA. 


\section{KAYNAKLAR}

1. Cooper DB, Mahdy H. Oral contraceptive pills [Internet]. Treasure Island (FL): StatPearls Publishing; 2019, 8 p. Available from: https://www.ncbi.nlm.nih.gov/books/ NBK430882/.

2. Golobof A, Kiley J. The current status of oral contraceptives: progress and recent innovations. Semin Reprod Med. 2016;34(3):145-51.

3. Bitzer J, Simon JA. Current issues and available options in combined hormonal contraception. Contraception. 2011;84(4):342-56.

4. Burkman RT, Collins JA, Shulman LP, Williams JK. Current perspectives on oral contraceptive use. Am J Obstet Gynecol. 2001;185(2):S4-S12.

5. Wakeman MP. A Review of the Effects of Oral Contraceptives on nutrient status, with especial consideration to folate in UK. J Adv Med Med Res. 2019:1-17.

6. Lussana F, Zighetti ML, Bucciarelli P, Cugno M, Cattaneo M. Blood levels of homocysteine, folate, vitamin B6 and B12 in women using oral contraceptives compared to non-users. TThromb. Res. 2003;112(1-2):37-41.

7. Cahill L, Corey PN, El-Sohemy A. Vitamin C deficiency in a population of young Canadian adults. Am. J. Epidemiol. 2009;170(4):464-71.

8. Shere M, Bapat P, Nickel C, Kapur B, Koren G. Association between use of oral contraceptives and folate status: a systematic review and meta-analysis. J Obstet Gynaecol Can. 2015;37(5):430-8.

9. Akinloye O, Adebayo T, Oguntibeju OO, Oparinde D, Ogunyemi E. Effects of contraceptives on serum trace elements, calcium and phosphorus levels. W Indian Med J. 2011;60(3):308-15.

10. Park B, Kim J. Oral contraceptive use, micronutrient deficiency, and obesity among premenopausal females in Korea: The necessity of dietary supplements and food intake improvement. PloS One. 2016;11(6):e0158177.

11. Colquitt CW, Martin TS. Contraceptive methods: A review of nonbarrier and barrier products. J. Pharm. Pract. 2017;30(1):130-5.

12. Christin-Maitre S. History of oral contraceptive drugs and their use worldwide. Best Pract Res Clin Endocrinol Metab. 2013;27(1):3-12.

13. Daniels K, Abma JC. Centers for Disease Control and Prevention (CDC). Current Contraceptive Status among Women Aged 15-49: United States, 2015-2017. NCHS Data Brief. 2018; 327.
14. Türkiye Beslenme ve Sağlık Araştırması (TBSA), T.C. Sağlık Bakanlığı Halk Sağlığı Genel Müdürlüğü, 1132, Ankara, 2019.

15. Committee on Practice Bulletins-Gynecology. Noncontraceptive uses of hormonal contraceptives, ACOG Practice Bulletin No. 110. Obstetrics \& Gynecology. 2010;115(1):206-18.

16. Caserta D, Ralli E, Matteucci E, Bordi G, Mallozzi M, Moscarini M. Combined oral contraceptives: health benefits beyond contraception. Panminerva Med. 2014;56(3):233-44.

17. Sherif K. Benefits and risks of oral contraceptives. Am J Obstet Gynecol. 1999;180(6):S343-S8.

18. Peck R, Norris C. Significant risks of oral contraceptives (OCPs): Why this drug class should not be included in a preventive care mandate. Linacre Q. 2012;79(1):41-56.

19. Shufelt CL, Merz CNB. Contraceptive hormone use and cardiovascular disease. J Am Coll Cardiol. 2009;53(3):22131.

20. Cornish JA, Tan E, Simillis C, Clark SK, Teare J, Tekkis PP. The risk of oral contraceptives in the etiology of inflammatory bowel disease: a meta-analysis. Am J Gastroenterol. 2008;103(9):2394-400.

21. Kamp F, Rodrigues TSL, Donangelo CM. Effect of oral contraceptive use and zinc supplementation on zinc, iron and copper biochemical indices in young women. E Spen Eur E J Clin Nutr Metab. 2011;6(6):e253-e8.

22. Morris MS, Picciano MF, Jacques PF, Selhub J. Plasma pyridoxal 5'-phosphate in the US population: the National Health and Nutrition Examination Survey, 2003-2004. Am J Clin Nutr. 2008;87(5):1446-54.

23. Shojania AM, Wylie B. The effect of oral contraceptives on vitamin B12 metabolism. Am J Obstet Gynecol. 1979;135(1):129-34.

24. Wilson SM, Bivins BN, Russell KA, Bailey LB. Oral contraceptive use: impact on folate, vitamin B6, and vitamin B12 status. Nutr. Rev. 2011;69(10):572-83.

25. Dante G, Vaiarelli A, Facchinetti F. Vitamin and mineral needs during the oral contraceptive therapy: A systematic review. Int J Reprod Contracept Obstet Gynecol. 2014;3(1):1-10.

26. Shojania AM. Oral contraceptives: effect of folate and vitamin B12 metabolism. Can. Med. Assoc. J. 1982;126(3):244.

27. Gardyn J, Mittelman M, Zlotnik J, Sela B, Cohen A. Oral contraceptives can cause falsely low vitamin B12 levels. Acta Haematol. 2000;104(1):22-4.

28. Streiff RR. Folate deficiency and oral contraceptives. JAMA. 1970;214(1):105-8. 
29. Smith J, Goldsmith G, Lawrence J. Effects of oral contraceptive steroids on vitamin and lipid levels in serum. Am J Clin Nutr. 1975;28(4):371-6.

30. Zal F, Mostafavi-Pour Z, Amini F, Heidari A. Effect of vitamin $\mathrm{E}$ and $\mathrm{C}$ supplements on lipid peroxidation and GSH-dependent antioxidant enzyme status in the blood of women consuming oral contraceptives. Contraception. 2012;86(1):62-6.

31. Kuohung W, Borgatta L, Stubblefield P. Low-dose oral contraceptives and bone mineral density: an evidencebased analysis. Contraception. 2000;61(2):77-82.

32. Gambacciani M, Cappagli B, Lazzarini V, Ciaponi M, Fruzzetti F, Genazzani AR. Longitudinal evaluation of perimenopausal bone loss: effects of different low dose oral contraceptive preparations on bone mineral density. Maturitas. 2006;54(2):176-80.

33. Gambacciani M, Ciaponi M, Cappagli B, Benussi C, Genazzani A. Longitudinal evaluation of perimenopausal femoral bone loss: effects of a low-dose oral contraceptive preparation on bone mineral density and metabolism. Osteoporosis Int. 2000;11(6):544-8.

34. Zittermann A. Decreased urinary calcium loss and lower bone turnover in young oral contraceptive users. Metab. Clin. Exp. 2000;49(8):1078-82.
35. Milman N, Clausen J, Byg KE. Iron status in 268 Danish women aged 18-30 years: influence of menstruation, contraceptive method, and iron supplementation. Ann Hematol. 1998;77(1-2):13-9.

36. Fraser IS, Jensen J, Schaefers M, Mellinger U, Parke $\mathrm{S}$, Serrani M. Normalization of blood loss in women with heavy menstrual bleeding treated with an oral contraceptive containing estradiol valerate/dienogest. Contraception. 2012;86(2):96-101.

37. Corbo MD, Lam J. Zinc deficiency and its management in the pediatric population: A literature review and proposed etiologic classification. J Am Acad Dermatol. 2013;69(4):616-24. e1.

38. Fallah S, Sani FV, Firoozrai M. Effect of contraceptive pill on the selenium and zinc status of healthy subjects. Contraception. 2009;80(1):40-3.

39. Mishu FA, Mia MAR, Ferdous N, Sarkar S. Study of serum zinc status in Bangladeshi women taking oral contraceptives. Birdem Med. J. 2020;10(1):12-5.

40. McCall KA, Huang C, Fierke CA. Function and mechanism of zinc metalloenzymes. Nutr. J. 2000;130(5):1437S-46S. 